\title{
Sustaining subsistence culture in Mamar agroforestry management in West Timor, is it possible?
}

\author{
Alfred Umbu Kuala Ngaji ${ }^{1,2^{*}}$, Muhammad Baiquni ${ }^{3,4}$, Hatma Suryatmojo ${ }^{5}$, and Eko Haryono ${ }^{3,4}$ \\ ${ }^{1}$ Environmental Science Program, Universitas Gadjah Mada, Yogyakarta, Indonesia \\ ${ }^{2}$ Politeknik Pertanian Negeri Kupang, Nusa Tenggara Timur, Indonesia \\ ${ }^{3}$ Faculty of Geography, Universitas Gadjah Mada, Yogyakarta, Indonesia \\ ${ }^{4}$ Graduate School, Universitas Gadjah Mada, Yogyakarta, Indonesia \\ ${ }^{5}$ Faculty of Forestry, Universitas Gadjah Mada, Yogyakarta, Indonesia
}

\begin{abstract}
A subsistence culture which has moral values related to the protection of ancestral territories and the environment, must be maintained in the management of Mamar agroforestry. On the other hand, subsistence culture is often seen as a counter-modernization culture because it is not commercially oriented. This paper aims to provide an overview of the subsistence culture and its relationship to the preservation of Mamar agroforestry and the potential stresses it faces, as well as quantify the opportunities for sustaining a subsistence culture in today's West Timorese society. The method used is literature study using Google Scholar and other relevant literature. As it is known, the demands of life necessities and lifestyles, global climate change, and government policies are the pressing factors for land conversion, including in Mamar. On the other hand, a culture of subsistence tends to maintain moral values in cultivating land that preserves nature, thereby reducing pressure for Mamar land conversion. The conclusion obtained is that a subsistence culture needs to be maintained and become a locomotive for maintaining the sustainability of development as a whole, by reducing the causes of vulnerability in society. Economic and social interests can be integrated due to compliance with strong social structures.
\end{abstract}

Keywords: Agroforestry, management, subsistence

\section{Introduction}

Subsistence culture is a culture that has been identified for a long time in the life of traditional communities in almost all over the world. This culture is generally synonymous with agricultural activities and is interpreted as a culture that produces food to meet personal and family needs. [1] in her research found that the subsistence culture of the West Timor dry land community contains moral values to conserve ancestral territory and natural resources as well as the comfort of community members in overcoming life difficulties, resulting in sustainable livelihoods. Because it needs to be maintained.

The statement shows the point of view [1] in assessing subsistence culture, namely on social and ecological aspects compared to economics, if using the triangular framework of the concept of sustainable development in [2, 3]. However, this framework demonstrates the need for a balance in three areas to support sustainable development. This condition will certainly raise questions and debate in its implementation.

As it is known, the demands of meeting the needs of life and lifestyle are currently quite urgent, which demands that people have sufficient capital. Purchasing power is an important measure in this case. Therefore, it is impossible to forget the economic aspect.

Economic-oriented development began after World War II, driven by the efforts of developed countries to recover from the tribulations caused by the War. Today's economy cannot be separated in development, although it is no longer as dominant as it was in the 1960s to 1970s because it considers the concept of sustainable development. Likewise in Indonesia, including West Timor. The subsistence culture in West Timor according to [1] is able to guarantee the sustainability of livelihoods.

\section{Method}

The method used in the preparation of this paper is a literature study using Google Scholar as a tool in searching for related literature. This was done because Google Scholar's reach was quite wide. In addition, a relevant literature search was carried out.

\section{Discussion}

* Corresponding author: alfredngaji2019@mail.ugm.ac.id 


\subsection{Mamar Agroforestry in West Timor and its development challenges}

The island of Timor is known as one of the areas in Indonesia that has a climate of type D or semiarid [4], [5]. Environmental pressures such as climate and land unsuitable for crop farming are dominant in limiting agricultural production in the region. These conditions force farmers to adjust farming patterns in order to survive [6]. The result of this adaptation then gave birth to a form of local wisdom, one of which is Mamar agroforestry.

Mamar is the name for traditional agroforestry in West Timor and is a permanent agricultural system developed around water sources by combining various long-lived and food crops with irregular cropping patterns [7], as well as livestock [8]. Because of this, Mamar is also one of the livelihood assets classified as natural capital.

The exploitation of Mamar as natural capital will be adjusted to the livelihood goals of the owner. The purpose of human life is also very much influenced by the values that develop and the existing demographic and natural conditions.

Population growth is one of the important factors that can greatly influence the form of Mamar exploitation. The Millennium Ecosystem Assessment (MA) in [9] states that an increase in population accompanied by an increase in demand tends to be expansive, which will reduce the quality and quantity of ecosystem services and environmental carrying capacity.

On the other hand, in [10] it is stated that the important values ecologically, economically, and socially are inherently related to sustainable forest development. Therefore, there are opportunities for changes in Mamar's exploitation in line with the changing values in society. The problem is the impact that changes in exploitation have had. Ecological, social and even economic impacts will be felt due to land use changes in Mamar. Therefore, the argument [1] to maintain a subsistence culture above becomes relevant because of the moral values to preserve ancestral heritage, natural resources and provide comfort for its citizens.

\subsection{Benefits of Mamar agroforestry}

From the results of existing research, it is known that agroforestry is very beneficial for protecting the environment, generally related to ecosystem services, including enriching the soil [11-14]. Apart from that, agroforestry also affects the quality of existing air and water [15-18]. Forest plants in agroforestry are said to play a role in carbon sequestration [19-21], creates a comfortable and cool microclimate and plays a role in providing water through its roots and canopy [22]. [23] stated that agroforestry contributes significantly to carbon sequestration, improves the regulation of ecosystem services, and increases biodiversity. Agroforestry can increase productivity and profitability [24-26] per unit of land in a sustainable manner. The socio-cultural function is also one part of the benefits of agroforestry as mentioned by [27, 28]. Agroforestry has traditionally served multiple purposes in the agrarian economy through various production and environmental benefits [29-32]. Regarding the formation of a microclimate, [33] indicated the large number of seedlings and weaning plants growing under trees in Mamar agroforestry due to the suitable microclimate.

As agroforestry, mamar on the island of Timor produces the same benefits, but mamar is still predominantly used to meet basic community needs or is still subsistence. The results of study [34], related to ecological, economic, and social studies, show that traditional agroforestry models perform relatively better functions compared to introduced agroforestry. However, introduced agroforestry is more flexible in its development. The polyculture nature of traditional agroforestry provides a more diverse range of benefits [35]. From an economic aspect, the contribution of traditional agroforestry to farmers' income is $60 \%$ to $95 \%$, and the financial feasibility is considered feasible based on the analysis of positive BCR and NPV values $(>1)$.

Mamar agroforestry is intended to protect water sources, as well as efforts to maintain community agricultural production [34]. In addition, Mamar is also known as a form of community effort to maintain sociocultural life, because the concept of Mamar comes from the term sirih (Ataupah, 1984) in [6]. It is known that betel and areca nut for the majority of the people of NTT, especially the island of Timor, are part of the culture of the people who act as intermediaries in their interactions [36].

In another part of his article, [35] mentions some of the benefits of mamar, namely in the preservation of water sources, land conservation, and provision of ecological environmental services due to the high diversity of plant species. [35] also said that the average gross margin per hectare of agroforestry value and production value per hectare of mamar agroforestry system is higher than non -mamar. Regarding production risks, most farmers in mamar and nonmamar agroforestry are risk averse; most of the mamar farmers are at the level of technical, economic and allocative efficiency and are quite efficient; and the level of environmental awareness of mamar farmers is greater than the level of environmental awareness of nonmamar farmers. However, Mamar's management is still heavily influenced by a strong subsistence culture.

\subsection{Subsistence culture}

Subsistence culture tends to have a negative connotation. Several characteristics of subsistence agriculture [37], namely: (a) only looking for primary commodities for daily consumption; (b) using low cultivation technology so that the quantity and quality of production is low; (C) rely on tradition in doing business, surrender and accept natural conditions; (d) it is not easy to adopt technology in agriculture; (e) "safety first," which means that farmers prefer to drink risk rather than maximize productivity; (f) agriculture is seen as a way of life and not just an income-generating activity. Farmers are generally more socially oriented, 
and make farming a living culture that is full of sociocultural values of the local community. A similar opinion was also expressed by [38].

Communities that practice a subsistence way of life are referred to as 'geographically isolated customary law communities'. This term tends to denote poverty and the primitive aspects of subsistence society that need to be integrated into the wider modern society

On the other hand, [1] argues that subsistence agriculture is a means as well as a culture to maintain their livelihoods on dry land. Dry land communities use a subsistence way of life to achieve common social goals and prioritize the balance of life with humans and nature, through determining moral values on how to meet needs - which are strengthened by the effectiveness of their social structures. A value that also exists in the subsistence culture of West Timor is that people value their way of life and land as important things they want to defend. Subsistence includes more than just survival and persistence by some communities because it represents a source of identity, resilience, and achievement [39, 40, 41].

\subsection{Effect of subsistence culture on Mamar agroforestry management}

Starting from the understanding that a subsistence culture emphasizes the balance of life with humans and nature, it is clear that agroforestry management will be carried out by paying attention to the principle of sustainability in accordance with the moral values held by the community. On the other hand, it is recognized that the inherent problems of dry land [42] combined with soil fertility, food chains and agricultural production are a concern during the period of global warming. This will cause the soil degradation process to occur faster. not only in hot and dry climates, but also in areas with very high rainfall (Stewart, Lal \& El-Swaify 1991 in [1]). This condition has implications for the vulnerability of rural communities in dry land areas which is much more severe, due to their heavy dependence on hydrological cycles and land use [1]. The fact is that rural communities have a considerable capacity to adapt to environmental degradation [38]. The results of Baiquni's research also concluded that there was high resilience to the moral values of society.

The arrangement in the management of Mamar is carried out by Fetor to maintain the balance of human life with nature, one of which is by applying the division of zones within the mamar area, namely the core zone, the buffer zone and the utilization zone [22], or the Aibaun zone. (sacred zone), Koppa zone (location for longevity crop development), perennial crop zone, and livestock raising zone [34]. Apart from preserving nature, this division provides a utilization zone as a place to grow crops for the community. The application of the "banu system", namely customary rules to regulate the harvest period, is also intended to protect the mother plant from the threat of extinction.

\subsection{Environmental pressure}

\subsubsection{Demands for meeting the needs of life and lifestyle}

The Millennium Ecosystem Assessment (MA) in [9] states that an increase in population coupled with an increase in demand tends to be expansive, causing enormous pressure on the earth and existing ecosystems, which in turn reduces the quality and quantity of ecosystem services and resources. support the environment. In this regard, the population in the West Timor region has continued to increase from time to time. BPS data show that the population growth in West Timor averaged $1.93 \%$ per year during the 2000 to 2010 period.

On the other hand, in [10] it is stated that important ecological, economic and social values are inherently related to sustainable forest development. Forest dynamics will affect the ecological, economic and social conditions of the community.

The increase in population clearly requires living space other than food and the fulfillment of other basic non-food needs. For the provision of living space, if there is no livelihood strategy carried out by moving places, the longer, the living space for the family of farmers will be smaller. The need for living space will encourage land conversion which also has an impact on the carrying capacity of ecosystem services. So expansion is an easy way to do it, but if it is done at the expense of its natural capital, it will cause environmental degradation. It is in this context that the existence of mamar agroforestry is threatened.

On the other hand, threats to agroforestry also come from lifestyle demands. The development of information technology such as mobile phones and the internet makes it easy for people to access information from all over the world, which changes people's mindsets and even behavior. This encourages the community to make various efforts both those that have considered environmental sustainability and those that have not. Therefore, meeting these needs can be done through land conversion and even land sales, as happened in several places in West Timor.

The results of the study [43] showed the trend of soil degradation within the mamar area for biomass production. This is thought to be due to the high intensity of activity in the mamar area. [35], also pointed to the use of chemical herbicides to clear agricultural land. This means that there is a pragmatic way of thinking in managing land, which unwittingly damages the environment. However, there are also activities that try to maintain the condition of mamar, which is shown from the results of research [35] related to the relatively high awareness of the environment around mamar.

\subsubsection{Government development policy}

It cannot be denied that the government has an important role in the development of a region. Increasing community welfare is the main keyword in development 
interventions which will certainly have a significant impact on society and the environment.

On the other hand, government policies are also inseparable from the development paradigm it is developing and the global context. The influence of political ecology on development is a challenge that must be watched out for. With a development paradigm that tends to prioritize economic growth, it is almost identical to the exploitation of nature. The principle of increasing ecological potential to become economically useful in extractivism theory reinforces the tendency to exploit nature.

NTT Province occupies the third highest number of poor people nationally. The number of poor people in NTT was $21.38 \%$ in September 2017, much higher than the national average of $10.12 \%$ poor people [44]. Under these conditions, it is not surprising that the Governor's main program is poverty alleviation. The economic approach cannot be separated from this effort. The problem is, what strategy will be used for this effort? Whatever the strategy is, the principle of sustainability must be at the forefront of development and not just political jargon

\subsubsection{Global climate change}

Global warming is presumably causing a lot of pressure on people's lives and encouraging changes in people's behavior. This is confirmed by [42] that upland rural communities are the most vulnerable group in the era of global warming. Dependence on the hydrological cycle of rural communities in dry upland areas is an important reason besides land use patterns.

Crisis due to global warming and other crises such as the one that occurred in 1998-2003 in Indonesia and the world in the past, has proven to be balanced by the lifestyle and culture of rural communities [38]. This is thought to be driven by the existing subsistence culture.

\subsection{Is it possible to maintain a culture of subsistence in Mamar agroforestry management?}

Based on the results of their research, [1] also found three things that cause the vulnerability of the livelihoods of rural dryland communities in West Timor, namely: (1) lack of market access and educational facilities; (2) lack of education in the community of elders and village representatives; (3) appoint village heads and other influential figures based solely on the lineage system. These things have an impact on village development.

The lack of education and leadership abilities of the village head results in less than optimal ways of leading, which in turn has an impact on the lack of protection of the community. On the other hand, the social structure of community livelihoods is heavily influenced by customary law which requires them to show respect for the elders (customary leaders), including the new bureaucracy led by the village head. This is a dilemma in community life in the village.
The position of the village head as a regional leader cannot be separated from the bureaucratic administration. Therefore, the capacity of the village head also determines the course of development in the village. The policy of a higher authority if it is not in accordance with the conditions of the natural environment and society can still be implemented, and the subsistence of society cannot refuse. On the other hand, abuse can occur because of the subsistence society moral values that have been built up over several generations.

Positive values in the form of respect for social structures that exist in a subsistence culture can be a strong point but also a weak point. However, from the perspective of sustainable development as described in the triangle concept of sustainable development by [2], [3], subsistence culture has a good chance to become the locomotive of sustainable development. Economic and social aspects can easily be integrated into sustainable development, provided there are improvements to the causes of vulnerability in the community. The strong influence of the leader can be an ideal entry point to ward off bad influences from outside. [1] concluded that what is needed is awareness, equality, and respect for subsistence cultural values in order to achieve a sustainable life

\section{Conclusion}

The subsistence culture that lives and develops in West Timorese society has deep-rooted moral values and is closely related to how society maintains a balance of life with humans and nature. Therefore, the existing subsistence cultural values need to be seriously considered to be maintained.

The integration of economic and social interests in a subsistence culture is very possible because of the fulfillment of the basic capital of social structures in society. However, improvements need to be made to minimize the problems that cause vulnerability so that this subsistence culture can optimally support sustainable development.

The writing of this paper is supported by the Ministry of Education and Culture through educational scholarships at UGM. Thanks also to the promoters who have contributed to the writing of this paper. without title.

\section{References}

1. Y. Tjoe, Sustaining Livelihoods: An Analysis of Dryland Communities in West Timor, Indonesia Submitted in fulfilment of the requirements of the degree of, no. March. 2016.

2. I. Serageldin, A. Steer, Mak. Dev. Sustain. from concepts to action, 1994.

3. R.S. Rivai, I.S. Anugrah, Forum Penelit. Agro Ekon., 29,1:13(2016).

4. Y.P.E.S. Agu, E. Neonbeni, Savana Cendana, 4,1:12-16(2019) [in Bahasa Indonesia] doi: 10.32938/sc.v4i01.460.

5. G.N. Njurumana, T. Butarbutar, Info Hutan, 1:53- 
62(2008) [in Bahasa Indonesia]

6. N.D.Gerson, B.A. Victorino, P. Pratiwi, Njurumana, 5,5:473-484, 2008. [in Bahasa Indonesia]

7. J. Roshetko, Mulawarman, Wanatani di Nusa Tenggara: Ringkasan Hasil Lokakarya (2002) [in Bahasa Indonesia]

8. E. Somarriba, Agrofor. Syst., 19,3:233-240(1992), doi: 10.1007/BF00118781.

9. L. Muta'ali, Daya Dukung dan Daya Tampung Lingkungan Hidup Berbasis Jasa Ekosistem untuk Perencanaan Lingkungan Hidup, 1st ed. Yogyakarta: Badan Penerbit Fakultas Geografi UGM, 2019. [in Bahasa Indonesia]

10. M. Course, F. Ecology, Forest dynamics p. 243254, In: Introduction to Forestry and Natural Resources (2013)

11. K.R. Kirby, C. Potvin, For. Ecol. Manage., 246,23:208-221(2007). 10.1016/j.foreco.2007.03.072.

12. B.M. Kumar, Carbon sequestration potential of Agroforestry systems. Florida, USA, 2011.

13. L.E. Buck, J.P. Lassoie, E.C.M. Fernandes, Agroforestry in Sustainable Agricultural Systems. (1999).

14. G. Schroth, F.L. Sinclair, Impacts of trees on the fertility of agricultural soils. In: Trees, crops and soil fertility: concepts and research methods. p. 111, (2009), doi: 10.1079/9780851995939.0001.

15. R.P. Udawatta, J.J. Krstansky, G.S. Henderson, H.E. Garrett, J. Environ. Qual., 31, 4:12141225(2002), doi: 10.2134/jeq2002.1214.

16. K.H. Lee, S. Jose, Agrofor. Syst., 58,1:4554(2003), doi: 10.1023/A:1025404019211.

17. M.L. López-Díaz, V. Rolo, R. Benítez, G. Moreno, Agrofor. Syst., 89,4:587-598(2015), doi: 10.1007/s10457-015-9793-y.

18. S.H. Anderson, R.P. Udawatta, T. Seobi, H.E. Garrett, Agrofor. Syst., 75,1:5-16(2009), doi: 10.1007/s10457-008-9128-3.

19. D.G. Kim, M.U.F. Kirschbaum, T.L. Beedy, Agric. Ecosyst. Environ., 226,65-78(2016), doi: 10.1016/j.agee.2016.04.011.

20. S.H. Sharrow S. Ismail, Agrofor. Syst., 60,2:123130(2004) doi: 10.1023/B:AGFO.0000013267.87896.41.

21. M.R. Mosquera-Losada et al., Land use policy, 78, (2018), doi: 10.1016/j.landusepol.2018.06.052.

22. C. Asdak, Hidrologi dan Pengelolaan Daerah Aliran Sungai. Yogyakarta: Gajah Mada University Press, (2007).

23. S. Kay et al., Land use policy, 83:581-593(2019), doi: 10.1016/j.landusepol.2019.02.025.

24. A. R. Graves et al., Ecol. Eng., 29,4:434449(2007), doi: 10.1016/j.ecoleng.2006.09.018.

25. M. Castro, Management of agroforestry systems : ecological, social and economic approaches (2016).

26. A. Rigueiro-Rodríguez, M.R. Mosquera-Losada, and E. Fernández-nuñez, L. Degrad. Dev., 23,3:227-241, (2012), doi: 10.1002/ldr.1072.

27. P. Tsonkova, C. Böhm, A. Quinkenstein, and D. Freese, Agrofor. Syst., 85, 1:133-152(2012), doi: 10.1007/s10457-012-9494-8.

28. T. Plieninger, Landsc. Res., 36,4:435-454, (2011), doi: 10.1080/01426397.2011.582943.

29. M. P. Eichhorn et al., Agrofor. Syst., 67, 1, 2950, 2006, doi: 10.1007/s10457-005-1111-7.

30. A. Rigueiro-Rodríguez, E. Fernández-Núñez, P. González-Hernández, J. H. McAdam, and M. R. Mosquera-Losada, Agrofor. Eur., 43-65, 2009, doi: 10.1007/978-1-4020-8272-6 3.

31. P. K. R. Nair, An Introduction to Agroforestry., 23, 4. Ganesville, Florida: Kluwer Academic Publishers, 1993.

32. M.R. Mosquera-Losada et al., EU FP7 Res. Proj. AGFORWARD 613520, 8.23, p. 95, 2016.

33. G.N. Njurumana, Pola Pengelompokan Komunitas Mamar Di Timor. Yogyakarta: Fakultas Pertanian UGM, 2009.

34. E. Pujiono, S.A.S. Raharjo, G. Njurumana, B. Dwi, H. Rianawati, Kajian Aspek Ekologi, Ekonomi Dan Sosial Model-Model Agroforestri Di Nusa Tenggara Timur, In: Prosiding Seminar Nasional Agroforestri. 456-461, (2013). [in Bahasa Indonesia]

35. J. Suek, Resiko, Inefisiensi dan Keberlanjutan Sistem Wanatani di Wilayah Timor Barat. Yogyakarta: Universitas Gadjah Mada, 2018. [in Bahasa Indonesia]

36. Y. Sumu, Salam, 4:16-18(2003).

37. N. Yudiarini, DwijenAGRO, 2, 1, (2004). [in Bahasa Indonesia]

38. M. Baiquni, The Economic and Ecological Crises and Their Impact on Livelihood Strategies of Rural Households in Yogyakarta, In: Rural Livelihoods, Resources and Coping with Crisis in Indonesia, 3rd ed., M.J. Titus,P.P. Burgers, (Eds). ICAS/Amsterdam University Press, Amsterdam, (2007).

39. T.F. Thornton, North. Rev., 23,23:82-102(2001).

40. T.A. Crane, Ecol. Soc., 15,4, (2010), doi: 10.5751/es-03683-150419.

41. B. Colombi, Am. Indian Q., 36,1:75-97(2012), doi: 10.5250/amerindiquar.36.1.0075.

42. E.D.G. Fraser, A.J. Dougill, K. Hubacek, C.H. Quinn, J. Sendzimir, M. Termansen, Ecol. Soc., 16,3:01 (2011), doi: 10.5751/ES-03402-160303.

43. A.U. Ngaji N.M. Abolla, Land Quality Testing for Biomass Production in several Types of Lanuse at Fatuleu East Nusa Tenggara Indonesia. In: Orgatrop Proceeding, 51-60 (2017).

44. Bappenas, Profil dan Analisis Daerah (Provinsi: Nusa Tenggara Timur, 2017), (2017). [in Bahasa Indonesia] 